\title{
The Impact of Government Incentives onTrigona's Project Assessment in Peninsular Malaysia
}

\author{
IImas Abdurofi ${ }^{a, *}$ and Mohd Mansor Ismail ${ }^{b}$ \\ ${ }^{\mathrm{a}, \mathrm{b}}$ Institute of Agricultural and Food Policy Studies, \\ Universiti Putra Malaysia, Malaysia \\ *Email: ilmasmasan@gmail.com
}

\begin{abstract}
Trigona honey is very essential to provide alternative daily supplement for health purpose. However, recent development indicates the need for demand increase but the supply of the product is still limited. The Government has introduced certain policies to develop agricultural performance in the country to assist either farmers or companies to obtain highly profitable business. Normally the incentives offer to the tax exemption. However, lack of effectiveness of the program is still as a source of concern to the agricultural sector in view of potential of Trigona industry in Malaysia. Thus, the objective of this study is to assess the financial projection and identify the role Government tax incentives in boosting investment projects of Trigona farming in peninsular Malaysia. The instruments of financial appraisal are used in this study namely Net Present Value (NPV), Internal Rate of Return (IRR), Payback Period and Profitability Index (PI). Along with the scenarios of tax incentive are introduced as Pioneer Status (PS), Investment Tax Allowance (ITA), and Accelerated Capital Allowance (ACA). The results indicate that the financial assessment of Trigona farming is financially viable, highly profitable and able to recover its initial investment in the short term. Moreover, with a Government tax incentives, farms are more efficient and massively lucrative.
\end{abstract}

Keywords: Trigona farming, Capital budgeting techniques, Government tax incentives

\section{Introduction}

The problems in rearing $A$ cerana and $A$ mellifera prompted the industry to search for new species, that is, Trigona spp. The research and development on the technical, financial and economic aspects of commercializing Trigona spp.is urgently needed to complement the existing production of natural honey in the industry. Through research and development, apiaries in Malaysia have rooms for improvement which can lead to higher yields and to a sustainable industry while addressing urgent technical problems like better breed and queen rearing. As a longer term objective, selections of new species like Trigona spp need to be done to obtain good colony such as pests tolerant strains. By products such are royal jelly, pollen, propolis, and venom are still unexplored at the moment. Post-harvest drying of honey and downstream processing still remain untouched. All these technical aspects must be combine with financial and economic aspects before any suggestion to commercialize the Trigona farming.

Moreover, if natural honey production from Trigona spp. is feasible, this implies that, with increasing total domestic demand, the production of natural honey can contribute to the improvement of the country food trade balance [1]. Then other by products can also be harvested, such as, beeswax, propolis, royal jelly, pollination services, ecotourism, beverages, etc. which are associated with the beekeeping industry. On the Performance of beekeeping projects in Malaysia, a research carried out on the Impact of Government incentives on Beekeeping projects in Malaysia and independent projects where there is no incentives. The return of investment of the beekeeping projects under government incentives scheme programme is more profitable and efficient than that of the independent projects where there is no incentives [2]. Beekeepers of the subsidized projects can repay or get back the sum of their initial investment one year earlier than do others who do not receive subsidy; large-scale Beekeeping projects are suitable for investors who have large capital and are interested in the higher returns. He conclude that, government should promote more beekeeping in the country by providing incentives to the participants especially the small farmers and potential investors. Thus, the objective of the study is to assess the financial projection of Trigona farming and investigate the impact of government incentives to the future appraisal of the industry.

\section{Literature Review}

In this study, the analysis of project appraisal prvides a mutual understanding about firms profitability, return, and cost-benefit in the scope of private project evaluation. Capital budgeting plays a pivotal role in any organisation's financial management strategy. It is defined as the "process of evaluating and selecting long term investments that are consistent with the business's goal of maximising owner wealth" [3]. Typically every organisation that embarks on this process must take necessary steps to ensure that their decision making criteria supports the business's strategy and enhances its competitive advantage over its rivalries. Capital budgeting techniques is defined as the methods and techniques used to evaluate select an investment project. It helps managers to select projects 
with the highest profits at an acceptable risk. Many scholars and researchers agree that capital budgeting decisions are crucial to a business's performance [4]. Capital budgeting plays a crucial role in a business's competitive model. This explains why [5] state that capital budgeting is not a trivial task. A business whose ability to effectively develop a feasible mechanism for capital budgeting may gain a better competitive advantage to its rivalries in an environment characterised by change volatility [6]. The indicators of financial appraisal in this study [7], namely Net Present Value (NPV), Internal Rate of Return (IRR), Payback Period (PBP), and Profitability Index (PI). The Net Present Value is used as the most frequent to assessing company decisions criteria [8]. NPV describes the amount cash that the firms earn in the project. The negative outcome of NPV shows that the cost surpass the benefit and the project is not economically viable. Internal rate return (IRR) is one of the commonly employed in evaluation, demonstrate the profitability of a single project which is very clear and apparent for the investors to digest. Normally if the value of IRR is positive and higher than the discount rate, it shows that the project is acceptable [9]. The Benefit Cost Ratio (BCR) indicates the ratio of the present valueof cost, if the ratio is greater than 1 , it shows that the project is viable and worthy of investing [10]. Additionally, [11] highlight the role of payback as very important to decide the acceptability of an investment project and highly determine how fast will to recover the cash resource that has been used to finance the project.

Malaysian Industrial Development Authority has outlines Government incentives to encourage investment and boost the potentials of agricultural, manufacturing and services sectors so the GDP is improve [12]. The predominant incentives for agricultural sectors are Pioneer Status (PS), Investment Tax Allowance (ITA), Accelerated Capital Allowance (ACA). Pioneer Status serves a partial exemption from company's tax. It incentives offer payment of $30 \%$ tax from statutory income for five years. Investment Tax Allowance grants the agriculture firms to offset the allowance against $70 \%$ from statutory income in the year of assessment and unutilized allowance will be carried forward to years to come till fully utilized. On the other hand, Accelerated Capital Allowance, provides an initial allowance in the first year and about $40 \%$ for an annual allowance. Normally, the incentives the conjoined package between Pioneer Status with Accelerated Capital Allowance and Investment Allowance with Capital Allowance to properly maximise profit for the agricultural companies.

\section{Research Method}

The study focuses on primary data from administering questionnaires via face - face interview with the Trigona beekeepers in Peninsular Malaysia. The source of data collection includes basic financial data of input-output costs, farm initial investment and income statement from farm production reports. A multi-stage sampling initially uses as a sampling method and the targeted respondents are specifically categorized for the young Trigona's beekeepers. Thus, the study employs about to 39 Trigona's beekeepers.

The data analysis in this study applies the calculation of capital budgeting techniques as Net Present Value (NPV), Internal Rate of Return (IRR), Profitability Index (PI), and Payback Period. The discount rate is imposed to determine a time value of money to the cost of capital as $10 \%$ during the project assessment. Along with fundamental assessment of financial appraisal, the adoption of government tax incentives in the financial projection is also implemented to find the impact between those variables. The tools of financial analysis are shown in the following mathematical expression below:

1. Net Present Value is also known as discounted cash flow technique. The positive result of NPV indicates the project is financially viable and accepted. The formula below is used in calculation:

$$
\begin{aligned}
& N P V=\sum_{t=0}^{N} \frac{C F_{t}}{(1+r)^{t}} \\
& \text { Where, } \\
& \mathrm{CF}=\text { Cash Flow } \\
& \mathrm{r}=\text { Discount Rate } \\
& \mathrm{t}=\text { Time }
\end{aligned}
$$

2. Internal Rate Return (IRR). The IRR is the discount rate when the net profit value of the project equal to zero. A projects IRR should be compared to the company's cost of capital. The rate means the project must surpass to ceate positive shareholder wealth.

$$
\begin{aligned}
& N P V=\sum_{t=0}^{N} \frac{C F_{t}}{(1+I R R)^{t}}=0 \\
& \text { Where, } \\
& \text { CF = Cash Flow } \\
& \mathrm{r}=\text { Discount Rate } \\
& \mathrm{t}=\text { Time } \\
& \text { IRR = Internal Rate of Return }
\end{aligned}
$$

\section{Profitability Index (PI) or Benefit Cost Ratio (BCR)}

- The Profitability Index, is the present value of the project's cash flows divided by the cost. PI describes the potential profit from from each money invested.

$$
P I=\frac{P V \text { of future cash flows }}{\text { Initial cost }}=\frac{\sum_{t=0}^{N} \frac{C F_{t}}{(1+r)^{t}}}{C F_{0}}
$$

Where,

$\mathrm{CF}=$ Cash Flow

$r=$ Discount Rate

$\mathrm{t}=$ Time

$\mathrm{PV}=$ Present Value 
4. Payback Period - The payback period is the expected number of years require to recover the initial investment. Payback period can be calculated by:

$$
\text { Payback Period }=\frac{\text { Initial Investment }}{\text { Periodic Cash Flow }}
$$

\section{Result and Discussion}

The social economic of the farmers are presented in Table 1. Accordingly, the total Trigona farming are 39 beekeepers. The average land size is about 0.89 ha and the 103 hives is indicated as the total number of colonies in average. Beekeepers' age was divided into three groups; most of them (56.4\%) belong to the age of 26-35 years. Followed by the age above $36(30.8 \%)$ and the age of 20 $25(12.8 \%)$. Furthermore, majority $(61.5 \%)$ of beekeepers graduated from university background and acquired more than 1 year experience, while only $12.8 \%$ of them focused the Trigona farming as a main job.

Table 1. Social Economic of Trignona's Beekeepers

\begin{tabular}{|c|c|}
\hline Variables & Values \\
\hline Number of farms & 39 beekeepers \\
\hline Land size (average) & 0.89 ha \\
\hline Number of colony (average) & 103 hives \\
\hline \multicolumn{2}{|l|}{ Age distribution(years) } \\
\hline - $\quad 20-25$ & $12.8 \%$ \\
\hline - $\quad 26-35$ & $56.4 \%$ \\
\hline - $\quad 36$ above & $30.8 \%$ \\
\hline \multicolumn{2}{|l|}{ Educational level } \\
\hline - $\quad$ High School (SPM) & $38.5 \%$ \\
\hline - University & $61.5 \%$ \\
\hline \multicolumn{2}{|l|}{ Experience } \\
\hline - 1 year & $30.8 \%$ \\
\hline - Above 1year & $69.2 \%$ \\
\hline \multicolumn{2}{|l|}{ Job } \\
\hline - Beekeeking as main job & $12.8 \%$ \\
\hline - $\quad$ Part- time job & $87.2 \%$ \\
\hline
\end{tabular}

Based on NPV results on Figure. 1 shows an accepted projection to the financial appraisal since the outcome provides positive cash to the basic projection and all incentives schemes. In this case, the beekeepers may generate earnings and the project is financially viable. Where the government tax incentives applied, the values of NPV are improved. Among the tax incentive scenarios, a combined tax incentives between ITA and ACA is better than other schemes. Thus, Trigona beekeepers should explore ITA on ACA tax incentives scenario in their farming to obtain better viability

\section{NPV results}

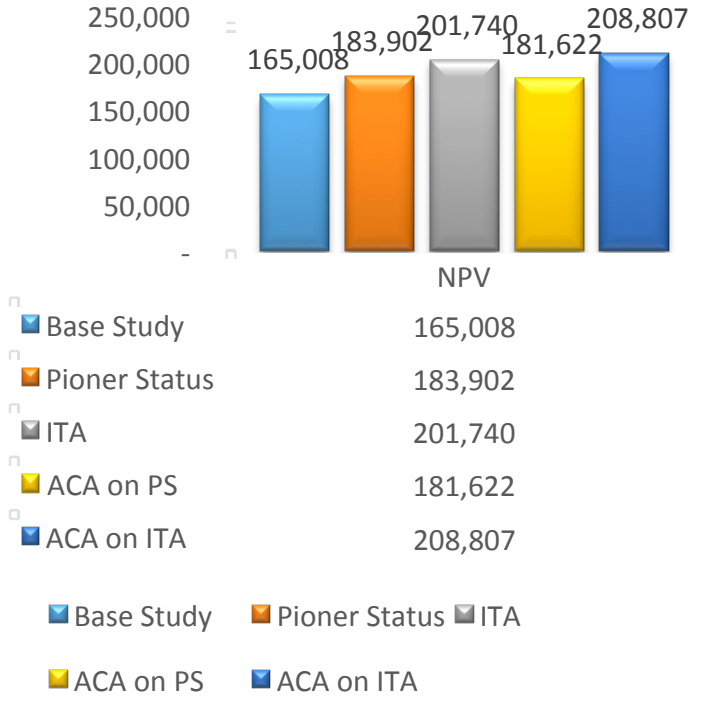

Figure 1. NPV results

Analyses of non-tax and tax incentives of Internal Rate of Return (IRR) is presented in figure 2. The non-tax incentive (base study) of IRR results $48 \%$ as more higher than discounted factors as $10 \%$, it can be concluded that the cash flow of this industry for the future income will drag positive outcome and reduce risk factors of the project. Moreover, the value of IRR also improves project's viability when the tax incentives are granted. In order to provide higher increased steam of income, the beekeepers should patronize the ITA on ACA tax incentives since the value constitutes as the most viable among other tax incentive scenarios.

\section{IRR Results}

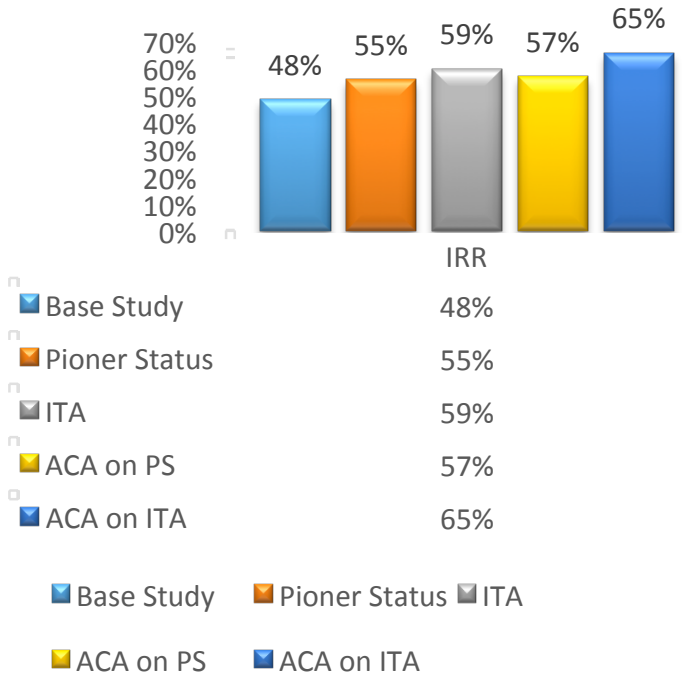

Figure 2. IRR results 
Relative to the results of Profitability Index (PI) with base period and tax incentives scenarios are indicated in figure 3. In terms of profitability index of base period (3.05) means the viability of the project; that the project can earn 2.05 cents per 1RM invested in the project; indeed, lucrative. Furthermore, in terms of the respective of tax scenarios, the tax incentive projects consistently show better viability; the ITA on ACA as the most gainful project with gain of RM2.59 per RM1 invested on cash return. Followed by ITA, PS and PS on ACA respectively.

\section{PI Results}

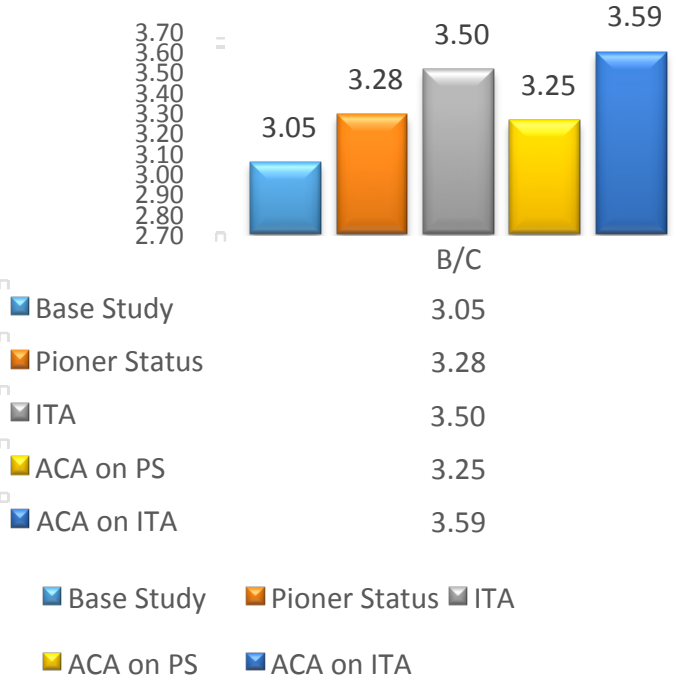

Figure 3. PI results

Figure 4 compares the effects of non-tax and government tax incentive scenarios for payback period of Trigona beekeepers. The PP indicator of non-tax incentive (base study) shows 2.04; this indicates that the project can recoup its invested capital under 3 years of operation. Depending on capital invested, but most agricultural projects require more than 5 years to payback their capital investment, thus, the paddy farming appears to be a visible option to recoup swiftly its invested capital. According to the tax incentives schemes, The ACA on ITA tax incentive shows the least payback period of about 1.39 years of recovery of invested capital, hence the need for beekeepers to explore this scenario is suggested for better income flows.

\section{PP Results}

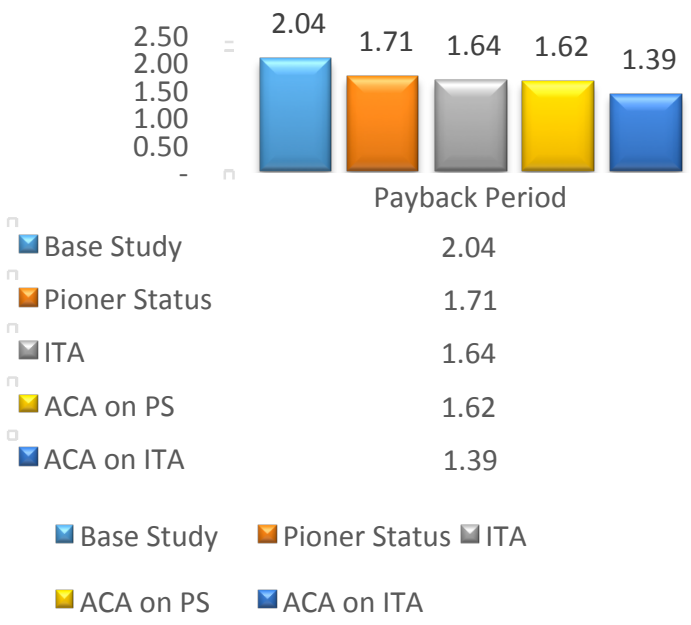

Figure 4. Payback Period results

\section{Conclusion}

The Trigona or stingless bee is a new activity in beekeeping industry that could complement natural honey production and pollination services. The potential of Trigona is tremendous and urgently need the further research due to the high demand and lack of supply. The present study applied financial analyses to determine the financial project of Trigona's beekeepers in the Peninsular Malaysia. All the financial indicators (NPV, IRR, PI, PP) indicates that Trigona farming is financially viable and a worthwhile venture. Results also illustrates that government tax incentives namely ITA, PS and ACA potentially increases the viability in Trigona farming. Furthermore, the outcomes also indicated that simultaneous tax-incentive as ACA on ITA enhances more viability relative to sole tax-incentive. In summary, this study found Trigona farming in Peninsular Malaysia is highly lucrative and shortness of recovery cycle of invested capital. Consequently, it is suggested that government should encourage the potentiality of Trigona farming to attract new beekeepers to involve in this industry, thus, the boost production will enhance the supply of Trigona honey in Malaysia.

\section{References}

[1] Ismail, M.M. (2014). Competitiveness of Beekeeping Industry in Malaysia. Inaugral Lecture Series, Dewan Pertanian, Faculti Pertanian, Universiti Putra Malaysia. Universiti Putra Malaysia Press, Serdang.

[2] Ismail, M.M. (2009). The Impact of Government Incentives on Beekeeping in Malaysia: A Case of Apis Mellifera. Proceedings of the $30^{\text {th }}$ Malaysian Society of Animal Production (MSAP), 2-5 June 2009, Kota Kinabalu, Sabah.

[3] Gitman, L.J. (2007). Principles of Managerial Finance, $11^{\text {th }}$ Edition, Pearson International.

[4] Arya, A.,Fellingham, J. C and Glover, J.C. (1998). Capital Budgeting: Some exceptions to the Net Presnt Rule, Issues in Accounting Education. Vol. 13 (3) pp. 499-508. 
[5] Kwak, W., Shi, Y., Lee, H., lee C.F. Capital Budgeting with Multiple Criteria and Multiple Decision Makers. Review of Quatitative Finance and Accounting, Vol 7, pp. 97-112.

[6] Lazaridis, I.T. (2004). Capital Budgeting Practices: A Survey in businesses of Cyrus, Journal of Small Business Management, Vol 42 (4), pp.427-433.

[7] Brigham, E. (2007). Fundamental of Financial Management. Dryden Press. New York.

[8] Sayed, Nezhadfahim, S.R, Eghdami, E, Yosefnezhad, Maleki, M. (2009). Investigating the Procedure of financial factors in successful Companies. Research Journal of Recent Science, 2(3), 44-48.

[9] Mackevicius,Jonas and Vladislav Tomasevic. (2010). Evaluation of Investment Projects inCase of conflict between the Internal Rate Return and the Net Present Value Method. Ekonomika Journal , 89(4), 116-130.
[10] Satyasai, K.J.S. (2009). Application of Modified Internal Rate of Return Method for watershed Evaluation. Agricultural Economic Research Review, 22, 401-406.

[11] Bordman, Calvin. M, Walter J. and Stephen E. Celec.(2006). The Role of Capital Payback Period in the Theory and Application of Duration to Capital Budgeting. Journal Business Finance and Accounting, 9(4), 511-522.

[12] Malaysian Industrial Development Authority.(2006). Malaysia - Incentives for Investment. Retrieved March 25, $2015 \mathrm{from} \mathrm{http//www.miti.gov.my/cms/content}$ 